\title{
Original Article \\ Relationship between perfectionism and narcissism with psychosocial adaptation in elite and non-elite athletes
}

\author{
*(D) Mohammad Hossein Namvar ${ }^{1}$ \\ Department of Physical Education, Tabriz branch, Islamic Azad University, Tabriz, Iran. \\ * Correspondence: hoseinnamvar9@gmail.com
}

Citation: Namvar, M.H; (2021). Relationship between perfectionism and narcissism with psychosocial adaptation in elite and non-elite athletes. Humanistic approach to sport and exercise studies (HASES), 1(1), 50-62.

\section{Received: 21 September 2021}

Accepted: 13 October 2021

Published: 09 November 2021

Publisher's Note: HASES stays neutral with regard to jurisdictional claims in published maps and institutional affiliations.

Copyright: () 2021 by the authors. Submitted for possible open access publication under the terms and conditions of the Creative Commons Attribution (CC BY) license.
Abstract: The present study aimed to investigate the relationship between perfectionism and narcissism with psychosocial adaptation in elite and non-elite athletes. A total of 200 elite and non-elite athletes (20-30 years old) who participated in the tournament of 2020 in Tabriz were randomly selected and completed the questionnaire of Sport Perfectionism - 2nd Dun et al. (2009 and 2010), Ruskin and Terry narcissism and Bell Social Adaptation Inventory. To analyze the results, Pearson correlation coefficient and simultaneous regression analysis were used. The results showed that in elite athletes group, there was a positive correlation between positive perfectionism (organizational and personal criteria) and psychological social adjustment, and between negative perfectionism (doubts about actions, perceived pressure of parents and perceived pressure of instructor) and narcissism with negative psychological social adjustment and both positive and negative perfectionism and narcissism variables could significantly predict social adjustment in elite athletes $(\mathrm{P}$ $<0.05$ ). In non-elite group between positive components of perfectionism, only the organizational component has a negative correlation with psychological social adjustment and the correlation between negative and narcissistic perfectionism components with positive social adjustment is positive. Among the components of perfectionism, the only negative components (too much importance by mistake, parental perception and perceived stress of the mentor) and the narcissistic variable have been able positively to predict psychosocial compatibility $(\mathrm{P}<0.05)$. Psychological social adjustment in athletes is one of the key variables in the professional and personal life of athletes, which is influenced by features such as perfectionism and narcissism.

Keywords: perfectionism, narcissism, psychological social adjustment, athlete, elite, non-elite;

\section{Introduction}

Today, adaptation is one of the most important signs of psychological health that is related in various fields of education, marriage, occupation, sports, etc. (Zarei Mousavieh, 2016). In this regard, one of the categories of adjustment is psychological social adjustment. The American Psychiatric Association (1994) defines psychosocial adaptation as the coordination of behavior to meet environmental needs that often require the correction of impulses, emotions, or attitudes
(Razmara, 2017). Thomas (1998) argues that social adjustment in the sports environment is not very different from other social environments. According to Thomas's theory of general social adjustment (1998), individuals engage in one or a set of five mechanisms when interacting socially, depending on the circumstances and cooperation, understanding, competition, escape, or situation in which they find themselves (Sukhov \& Derkach, 1998).

In social practice, the solution is considered when the conservatism of the individual has a sense of 
proportion towards the other party and sees his victory as dependent on his victory. In Thomas' theory, understanding is a prerequisite for cooperation. In hostile social situations, the feeling of enmity replaces the feeling of friendship. In this case, people not only want their victory, they also want the defeat of the other side. In this case, the person who feels empowered and superior calls the other party to "compete". Competition is a kind of social interaction in which one-sided victory requires the defeat of the other. Sports coaches and managers tend to have understanding and cooperation in their own team in the first place. They also prefer that in the face of opposing teams, the members of the home team have the greatest tendency to compete and the members of the opposing team have the greatest tendency to run away. For maximum motivation, some coaches turn their sense of competition into a feeling of hostility for their athletes and the competition scene into a battlefield. This means that the coach confirms the aggressive behavior. This is especially true in martial arts.

On the other hand, for hereditary or educational reasons, one or two of the five methods of social adjustment may prevail in a person and become a habit for him. In this way, individuals can be socially divided and given titles such as militant, compromising, conservative, and so on. According to some researchers, the predominant type of social adjustment of the athlete may be influential in the individual's decision to choose the type of sport. For example, it has been said that martial arts athletes are better off being psychologically aggressive and socially challenging. Conversely, in team disciplines, it is better for athletes to be more understanding and cooperative. Adaptation is affected by social, psychological and biological factors, so that negative emotions resulting from social problems can cause psychological or physical problems to interrupt this process. Among these possible factors, we can mention perfectionism (Zarei Mousavieh, 2016).

Perfectionism is defined as a personality trait and is defined as an extreme tendency to be flawless and to set very high standards for performance with a strong tendency to critically evaluate. In fact, perfectionists want to be perfect in every aspect of their lives. In sports, perfectionism means the athlete's persistent desire to set complete and unattainable standards and strive to achieve them, which may produce positive and negative behavioral and psychological outcomes among athletes, especially competitive athletes. Many studies believe that perfectionism includes dual dimensions of compatible and incompatible (positive and negative), and these dimensions can be distinguished from each other (Zarei Mousavieh, 2016).

People with positive perfectionism enjoy trying to achieve achievable goals, but negative perfectionists are those who experience high levels of anxiety and are very afraid of failure. Accordingly, positive perfectionists are driven to greater progress and are highly motivated. In his theory, Hamachek (1978) stated that normal and positive perfectionism is created by positive modeling (Hamachek, 1978). Abnormal and negative perfectionism arises from conditional assessment in the environment, lack of evaluation or cross-sectional and discontinuous evaluations (Öngen, 2009). Perfectionism can be considered as a multidimensional personality tendency that interferes with people's lives during their existence (Nascimento Junior et al., 2020; Stoeber, 2018) and perhaps for this reason, it has created a lot of curiosity and research, especially in the field of sports (Stoeber, 2018). In the field of sports, perfectionism manifests itself as a common feature in athletes at different levels of competition and can be associated with participation in sports and sports-related leisure activities (Vink \& Raudsepp, 2018), and reduce stress and exercise and affect the mental health and performance of these people (Zarei Mousavieh, 2016).

The results of Nasiri (2019) showed that there is a positive and significant relationship between the dimensions of perfectionism with mental health and social adjustment (Nasiri, 2019). Also, Jafari and Jajarmi (2015) research showed that there is a significant relationship between perfectionism and self-efficacy with adaptation (Jafari \& Jajarmi, 2015). Various studies on perfectionism have been conducted in the country that show a significant relationship between the dimensions of perfectionism in successful and unsuccessful karatekas and between positive and negative perfectionism with a motivation for progress (Vatankhah \& Samani, 2016). In another study, the results showed that there is a significant relationship between the dimensions of 
perfectionism and trait anxiety and perceived pressure of coaches (Arbab et al., 2016).

Waleriańczyk \& Stolarski (2021) in their study of personality and athletic performance: the role of perfectionism, five major characteristics and predicted performance in predicting the results of long-distance running, showed that perfectionist efforts significantly result in performance Predicted (Waleriańczyk \& Stolarski, 2021). In addition, perfectionist efforts moderated the relationship between predicted and actual performance. Nascimento Junior et al. (2020) also showed in their research that consistent perfectionism can be considered as an interfering factor in collective performance in futsal, especially in successful teams (Nascimento Junior et al., 2020).

Various studies have also been conducted on the relationship between perfectionism and personality traits. The results of research on the dimensions of perfectionism have confirmed the correlation of this structure with personality traits that there is a significant relationship between perfectionism and narcissism (Besharat et al., 2021). Therefore, one of the types of personality traits is narcissism, which sometimes becomes extreme and causes the isolation of the individual in the environment (Tazegül, 2017). Narcissism is conceived as "the ability of a person to maintain a positive self-image through a variety of self-emotional and regulatory processes" (Pourramzani \& Monajemi, 2021). In other words, narcissism is a socially distasteful personality trait that is characterized by a selfcentered, self-magnifying, dominant, and manipulative interpersonal orientation (Czarna et al., 2019).

In their research reports, Sadok and Kaplan (1998) found that narcissists are unique individuals who should be treated differently by others and who do not tolerate criticism and indifference and only consider themselves important and in relationships (Kaplan \& Sadock, 1988). Someone has exploitative behavior. In the eyes of most people, narcissists are arrogant, selfish, exploitative, rightwing and aggressive. In a word, narcissism is "..." bad and predicts other "bad" things. In fact, narcissism has been considered a pathological disorder since its inception in psychology (Cai \& Luo, 2018).

However, decades of research on narcissism in the general population have shown that to some extent and in some respects narcissism can be desirable and consistent (Baddeley, 1992; Sedikides et al., 2004). For example, narcissists tend to be confident, assertive, extroverted, energetic, and happy (Watson \& Biderman, 1993) and are more likely to have high self-esteem and are less likely to experience depression and anxiety (Sedikides et al., 2004).

On the other hand, Pulakos et al. (2002) reported different relationships between adaptation aspects and personality traits. But none of the available research has included narcissism (Pulakos et al., 2002). However, Foster et al. (2009) and Grijalva \& Zhang (2016) stated that narcissists find themselves very adaptable (Foster et al., 2009; Grijalva \& Newman, 2015). Findings from Smith \& Webster (2018) also show that narcissism indirectly affects innovation through adaptation (Smith \& Webster, 2018). To understand the psychology of sports heroes, researchers have examined the differences between heroes and non-heroes in different sports in terms of personality dimensions, and some studies suggest that sports heroes are more emotionally stable and outgoing. They are also superior in self-expression and self-confidence to athletes who are not at championship level (Cox \& Yoo, 1995).

In different studies, they examined the relationship between narcissism and positive thinking at different levels of athletes with disabilities and compared the level of narcissism of students of the Faculty of Sports Sciences in terms of demographic variables. The results showed that there is a positive relationship between narcissism scores and positive thinking skills of athletes with disabilities, but no significant difference was observed in any of the dimensions and indicators compared (Tazegül, 2017).

Unfortunately, in the field of the present study, no research has been done that is directly related to the subject, which doubles the importance and necessity of the present study. In general, the results of this research show the positive and negative effects of perfectionism and narcissism as a personality trait on mood and athletic performance in such a way that considering high criteria is an integral part of elite athletes and has an effect. It is a motivation that encourages people to achieve perfection and achieve goals. Also, by creating a lively and fresh spirit, it will provide the ground for social adjustment in the individual, which is often beneficial for athletic performance; but if the athlete 
only expects flawless performance, if this demand is not met, his expectation will lead to a negative reaction to the mistake, self-blame and fear of failure (Waleriańczyk \& Stolarski, 2021).

In previous studies, different results have been obtained in the field of relationship between research variables separately and also research variables have not been used as a study together in a single study, but this study tries to provide a general and comprehensive review. The other rooted in sports psychology. Also little research has been worked about the relationship between personality traits such as athletes' perfectionism and narcissism on psychological and social adjustment, especially elite athletes (someone who has competed now or in the past as an experienced player, a professional player or a national or international player) and non-elite (people who have trained as beginners and have not participated in international competitions), which is an important topic in this study; Because it seems to affect the types of reactions and performance of different athletes. Given the importance of the issue, this study intends to answer the question to what extent there is a relationship between perfectionism and narcissism with psychological social adjustment in elite and non-elite athletes?

\section{Materials and Methods}

The present study is applied in terms of purpose and descriptive-correlational in nature; which is done in the field. In the present study, in order to prevent the loss of subjects and incomplete questionnaires and increase the generalizability of the data, there were 200 athletes (elite and nonelite) in Tabriz with an age range of 19-30 years who participated in the competitions in 2019 were randomly selected from the statistical population.

The following scales and methods were used to collect research data.

Sports Perfectionism Questionnaire - 2 Dun et al. (2009 and 2010): This questionnaire has six subscales of personal criteria, excessive importance by mistake, parental pressure perception, coach pressure perception, skepticism about actions and organization and 42 The question is that each question has a score from 1 (completely disagree option) to 5 (strongly agree option).
The reliability of the tool in the present study for the subscale of personal criteria (0.64), excessive importance by mistake (0.79), parental pressure perception (0.80), coach pressure perception (0.78), ratio doubt It was obtained by applying (0.85) and organizing (0.86) and for total perfectionism by 0.88 .

B) Ruskin and Terry narcissism questionnaire: This questionnaire has 16 pairs of phrases and its purpose is to assess the characteristics of narcissism. The answer range from row A is one (1) point and for each question selected from row B is zero (0) points. In the present study, the reliability of Cronbach's alpha method was estimated to be 0.82 .

C) Bell Social Adjustment Questionnaire: The main form of the questionnaire measures general adjustment and has 160 questions that 5 components including home adjustment, job adjustment, health adjustment, emotional adjustment and socio-psychological adjustment are measured. Give. In this study, a subscale of sociopsychological adjustment was used which has 32 questions. The answer range is three options (yes = score 2 , no $=1$ and I do not know = zero). The reliability of the instrument was 0.79 by Cronbach's alpha method.

To conduct the research, he referred to the General Department of Sports and Youth of Tabriz. Then, after negotiating with the officials of the General Department of Sports and Youth of Tabriz and explaining the purpose of the research, they were asked to cooperate. Then, after the agreement of the relevant officials in a coordination meeting, the necessary information including the objectives of the study, how to respond to the tools and working methods were given to the technical staff and athletes. These explanations were given separately for both elite and non-elite athlete groups. After obtaining informed consent to participate in the research and knowledge of the purpose of the research, they completed the research questionnaires. Finally, after removing incomplete questionnaires, 92 questionnaires were collected from the elite group and 95 questionnaires were collected from the non-elite group.

Pearson correlation and simultaneous regression analysis were used to test the research hypotheses. Spss22 software was used for data analysis.

\section{Results}


Humanistic approach to sport and exercise studies (HASES); 2021, 1(1), 53 of 61

Table 1 provides information on the frequency of sample members in both elite and non-elite groups.

Table 1. Frequency related to group membership of sample people

\begin{tabular}{ccc}
\hline Group & \multicolumn{2}{c}{ Index } \\
\hline \multirow{2}{*}{ Elite } & $\mathrm{N}$ & 92 \\
\cline { 2 - 3 } & Percent & 46 \\
\hline Non-elite & $\mathrm{N}$ & 95 \\
\cline { 2 - 3 } & Percent & 47.5 \\
\hline Incomplete & $\mathrm{N}$ & 13 \\
\cline { 2 - 3 } & Percent & 6.5 \\
\hline
\end{tabular}

In Table 1, as shown, among the participants in the study, 92 are in the elite group and 95 are in the non-elite group.

Table 2. Frequency distribution of age of sample group members

\begin{tabular}{ccccc}
\hline Groups & \multicolumn{2}{c}{ Elite } & \multicolumn{2}{c}{ None-elite } \\
\hline Age & $\mathrm{N}$ & percent & $\mathrm{N}$ & percent \\
\hline $19-24$ & 48 & 52.18 & 51 & 53.78 \\
\hline $25-30$ & 44 & 47.82 & 44 & 46.32 \\
\hline Total & 92 & 100 & 95 & 100 \\
\hline
\end{tabular}

Table 2 shows the frequency information of the sample members.

Table 3. Correlation coefficient between perfectionism and its components with psychological and social adjustment

\begin{tabular}{|c|c|c|c|c|c|c|c|c|}
\hline Variable & $\mathbf{1}$ & 2 & 3 & 4 & 5 & 6 & 7 & 8 \\
\hline Doubt about actions & 1 & & & & & & & \\
\hline Organizing & -0.14 & 1 & & & & & & \\
\hline Personal criteria & -0.30 & $* *_{-} 0.71$ & $*-0.41$ & 1 & & & & \\
\hline Too important to be wrong & 0.13 & $* *$-.71 & $*-.41$ & 1 & & & & \\
\hline Perception of parental pressure & 0.19 & $* *-0.71$ & -0.31 & $* * 0.69$ & 1 & & & \\
\hline Perception of coach pressure & 0.29 & $* *-0.55$ & -0.20 & $* * 0.52$ & $* * 0.77$ & 1 & & \\
\hline Total perfectionism & $* * 0.91$ & $* * 0.93$ & $* * 0.76$ & $* * 0.68$ & $* * 0.77$ & $* *_{-} 0.72$ & 1 & \\
\hline Psychosocial adjustment & $* *-0.38$ & $* * 0.14$ & $* * 0.33$ & $* *_{-} 0.01$ & $* *-0.13$ & $*_{-0.41}$ & $*_{-0.38}$ & 1 \\
\hline
\end{tabular}

As the results of the table show $(\mathrm{P}<0.01, \mathrm{P}<0.05)$ there is a significant correlation between perfectionism and psychological social adjustment in elite athletes.

Table 4. Correlation coefficient between narcissism and psychosocial adjustment in the elite group

\begin{tabular}{lll}
\hline Variable & 1 & 2 \\
\hline Narcissism & 1 & \\
\hline Socio-psychological adjustment & -0.31 & 1 \\
\hline
\end{tabular}

As the results of the table show, there is a negative and significant relationship between narcissism and psychological and social adjustment of elite athletes ( $\mathrm{P}>0.05)$. In other words, with the increase of narcissism, their adaptation decreases, and in contrast, with the decrease of narcissism, their psychological and social adjustment increases.

Table 5. Summary of ANOVA regression analysis results

\begin{tabular}{lccccc}
\hline Model & Total squares & Mean Squares & df & F & Sig. \\
\hline Regression & 127.41 & 18.20 & 7 & 2.26 & 0.05 \\
\hline Left Over & 184.58 & 8.02 & 23 & & \\
\hline Total & 312 & & 30 & & \\
\hline
\end{tabular}

Based on the findings of Table 5, according to the significance of the predictor variable, regression method can be used to predict psychological and social adjustment.

Table 6. Simultaneous regression analysis of psychosocial adjustment based on perfectionism and narcissism

\begin{tabular}{|c|c|c|c|c|c|c|}
\hline \multirow[t]{2}{*}{ Model } & \multicolumn{2}{|c|}{$\begin{array}{l}\text { Non-standard } \\
\text { coefficients }\end{array}$} & \multirow{2}{*}{$\begin{array}{r}\text { Standard } \\
\text { coefficients } \\
\beta\end{array}$} & \multirow[t]{2}{*}{$\mathrm{t}$} & \multirow[t]{2}{*}{ Sig. } & \multirow[t]{2}{*}{$\begin{array}{c}\mathrm{R} \\
\text { Square }\end{array}$} \\
\hline & B & Std. dev. & & & & \\
\hline fixed amount & -3.09 & 9.10 & - & -0.34 & 0.001 & 0.40 \\
\hline
\end{tabular}


Humanistic approach to sport and exercise studies (HASES); 2021, 1(1), 54 of 61

\begin{tabular}{lccccc}
\hline Doubt about actions & -0.25 & 0.15 & -0.17 & -0.33 & 0.01 \\
\hline Organizing & 0.32 & 0.25 & 0.44 & 1.65 & 0.01 \\
\hline Personal criteria & 0.39 & 0.23 & 0.55 & 2.82 & 0.01 \\
\hline Too important to be wrong & -0.29 & 0.49 & -0.16 & -0.58 & 0.01 \\
\hline Perception of parental pressure & 0.03 & 0.33 & 0.39 & 1.20 & 0.24 \\
\hline Perception of coach pressure & -0.40 & 0.19 & -0.36 & -0.15 & -0.001 \\
\hline Total perfectionism & -0.36 & 0.08 & -1 & 3.15 & 0.004 \\
\hline Psychosocial adjustment & -1.03 & 0.39 & -0.90 & 2.62 & 0.001 \\
\hline
\end{tabular}

The findings in Table 6 show that the predictor variables of perfectionism and its components include (organization, personal criteria, skepticism about actions, excessive importance to error and perception of coach pressure) and narcissism has been able to predict psychosocial adjustment.

Table 7. Correlation coefficient between perfectionism and its components and psychological and social adjustment of

\begin{tabular}{|c|c|c|c|c|c|c|c|c|}
\hline Variable & 1 & 2 & 3 & 4 & 5 & 6 & 7 & 8 \\
\hline Doubt about actions & 1 & & & & & & & \\
\hline Organizing & $* *_{-} 0.87$ & 1 & & & & & & \\
\hline Personal criteria & $* *-0.66$ & $*^{*} *_{-0.56}$ & 1 & & & & & \\
\hline Too important to be wrong & $* * 0.50$ & $* *_{-} 0.67$ & 0.27 & 1 & & & & \\
\hline Perception of parental pressure & $* * 0.58$ & $* *_{-} 0.73$ & 0.30 & 0.84 & 1 & & & \\
\hline Perception of coach pressure & $* * 0.56$ & $* * 0.72$ & -0.32 & $* * 0.97$ & $* *_{-} .084$ & 1 & & \\
\hline Total perfectionism & $* * 0.91$ & $* * 0.93$ & $* * 0.76$ & $* * 0.68$ & $* * 0.77$ & $* *-0.72$ & 1 & \\
\hline Psychosocial adjustment & $* 0.39$ & $*_{-} 0.56$ & 0.19 & $* * 0.89$ & $* * 0.71$ & $* * 0.85$ & $* *-0.56$ & 1 \\
\hline
\end{tabular}

As the results of the table show, there is a positive and significant correlation between perfectionism and psychosocial adjustment in non-elite athletes $\left({ }^{* *} \mathrm{P}<0.01,{ }^{*} \mathrm{P}<0.05\right)$. This means that with increasing perfectionism, psychological social adjustment increases and conversely, with decreasing perfectionism, the adjustment rate decreases.

Table 8. Correlation coefficient between narcissism and psychological social adjustment of non-elite athletes

\begin{tabular}{lll}
\hline Variable & 1 & 2 \\
\hline Narcissism & 1 & \\
\hline Socio-psychological adjustment & 0.31 & 1 \\
\hline
\end{tabular}

Table 9. Simultaneous regression analysis of psychosocial adjustment based on perfectionism and narcissism

\begin{tabular}{|c|c|c|c|c|c|c|}
\hline \multirow[t]{2}{*}{ Model } & \multicolumn{2}{|c|}{$\begin{array}{l}\text { Non-standard } \\
\text { coefficients }\end{array}$} & \multirow{2}{*}{$\begin{array}{l}\text { Standard } \\
\text { coefficients }\end{array}$} & \multirow[t]{2}{*}{$\mathrm{t}$} & \multirow[t]{2}{*}{ Sig. } & \multirow[t]{2}{*}{$\begin{array}{c}\mathrm{R} \\
\text { Square }\end{array}$} \\
\hline & $\mathrm{B}$ & Std. dev. & & & & \\
\hline fixed amount & 25.94 & 8.33 & - & 3.11 & 0.005 & 0.80 \\
\hline Doubt about actions & 0.04 & 0.14 & 0.07 & 0.33 & 0.73 & \\
\hline Organizing & 0.04 & 0.14 & 0.07 & 0.31 & 0.75 & \\
\hline Personal criteria & 0.02 & 0.06 & 0.04 & 0.03 & 0.97 & \\
\hline Too important to be wrong & 0.76 & 0.23 & 1.48 & 3.26 & 0.004 & \\
\hline $\begin{array}{l}\text { Perception of parental } \\
\text { pressure }\end{array}$ & 0.12 & 0.11 & 0.04 & 0.22 & 0.004 & \\
\hline Perception of coach pressure & 0.30 & 0.25 & 0.57 & 1.19 & 00.4 & \\
\hline Total perfectionism & 0.09 & 0.02 & 0.56 & 3.65 & 0.001 & \\
\hline Psychosocial adjustment & 0.30 & 013 & 0.03 & 0.02 & 0.001 & \\
\hline
\end{tabular}


As the results of the table show, there is a positive and significant relationship between narcissism and psychological and social adjustment of non-elite athletes $(\mathrm{P}>0.05)$. In other words, with the increase of narcissism, their adaptation increases, and in contrast, with the decrease of narcissism, their psychological and social adjustment decreases. The findings of the table show that the predictor variables of perfectionism and its components including (excessive importance by mistake, perception of parental pressure and perception of coach pressure) and narcissism have been able to predict psychological and social adjustment.

\section{Discussion}

According to the results, there is a significant correlation between perfectionism and psychological social adjustment in elite athletes. So that there is a positive and significant correlation between the components of positive perfectionism including organization and personal criteria with psychological social adjustment and between the components of negative perfectionism including skepticism about actions, perception of parental pressure and perception of coach pressure with Psychosocial adjustment There is a significant negative correlation. This means that with increasing positive perfectionism, psychological social adjustment increases and vice versa, and with increasing negative perfectionism, the adjustment decreases. This finding is consistent with the findings of Rice and Dellow (2002) (Rice \& Dellwo, 2002), Watankhah and Samani (2015) (Vatankhah \& Samani, 2016), Besharat et al. (2011) (Besharat et al., 2021).

Rice and Dellow (2002) believe that positive perfectionism has a significant correlation with high personal criteria, good performance, and positive realistic adaptation (Rice \& Dellwo, 2002). Valeriansky and Stolarsky (2021) showed that perfectionist efforts significantly predicted the results of implementation (Waleriańczyk \& Stolarski, 2021). In addition, perfectionist efforts moderated the relationship between predicted and actual performance. Nacimonto Jr. et al. (202) also showed in their research that consistent perfectionism can be considered as an interfering factor in collective performance in futsal, especially in successful teams (Nascimento Junior et al., 2020). The results of Besharat et al. (2011) also showed that there is a positive correlation between positive perfectionism and achievement motivation with sports success and a negative correlation between negative dimensions of perfectionism and sports success (Besharat et al., 2021).

Therefore, it can be said that in order to achieve adaptation and success, the athlete always needs to maintain the desired level of perfectionism and the necessary motivation can be fruitful as a driving force to achieve peak performance. Explaining the results, it can be said that athletes and positive perfectionists have more psychological and social adjustment due to their high flexibility and experience of positive emotions; Positive perfectionists can positively express mental health and mental social adjustment by strengthening positive psychological areas such as trust, realism, flexibility, satisfaction, satisfaction with their performance, and vice versa, the negative dimension of perfectionism with Indices of incompatibility are correlated, such as negative emotions. In addition, negative perfectionists are dissatisfied with their situation and have more social and psychological incompatibility with their rejection of themselves and others and their inability to communicate positively.

Stoeber and Otto (2006) have pointed out in their research that the positive dimension of perfectionism has a significant relationship with various variables such as adjustment and social correlation (Stoeber \& Otto, 2006). According to Park and Jeong (2015), positive perfectionists are characterized by characteristics such as individual criteria and organizational skills (Park \& Jeong, 2015). With their high self-efficacy, they are able to dominate the environment, control existing opportunities and resources with a sense of autonomy and independence, and set clear goals. The combination of the above factors can increase the psychological and social adjustment of athletes. Explaining the results, we can also refer to the research of Enns et al (2002) who studied the positive and negative aspects of perfectionism and showed that normal perfectionism has motivational characteristics that strengthen one's efforts to achieve success (Enns et al., 2002). And it will lead to positive results. In addition, it may lead to the treatment of many mental disorders and helplessness, in which case perfectionism will play a positive role in one's development.

Perfectionism is a characteristic that, if formed in a normal and positive way in athletes, causes them to strive and improve their performance and success in sports, and if it is formed in a negative and abnormal way, it causes them to fall behind and intensify negative emotions such as aggression and despair. For this reason, it negatively affects the efficiency, ability and psychological factors of the individual, including the psychological and social adjustment of the workers. It can also be acknowledged that the positive dimension of perfectionism; In other words, considering personal criteria has a motivating effect and leads to positive moods and psychological and social adjustment in the person if the criteria are reasonable, the effort to achieve them is not extreme and beyond the ability of the person; Because in this case, the occurrence of negative moods and psychological helplessness 
will be inevitable. In fact, by shifting their focus from worrying aspects to perseverance and effort, athletes can better understand the logical dimensions of sporting situations and social adjustment in those situations.

In contrast, focusing too much on mistakes during competition causes the athlete to lose focus on performance, which ultimately leads to a reduction; therefore, he may consider himself a failure. In this way, this feeling of failure will cause him anger and depression and incompatibility. Excessive sensitivity to mistakes and blame causes the athlete to doubt his sense of worthiness and lose hope of achieving the desired criteria.

According to the results, there is a negative and significant relationship between narcissism and psychological and social adjustment of elite athletes. In other words, with the increase of narcissism, their adaptation decreases and in contrast, with the decrease of narcissism, their psychological and social adjustment increases. Accordingly, and according to the results, the relationship between narcissism and psychological social adjustment in elite athletes is confirmed. This finding is consistent with the findings of Houlcroft et al. (2012) (Houlcroft et al., 2012).

In other words, the results of this study indicate that elite athletic students have a low rate of narcissism. Narcissism is an important combination of personality traits and processes with characteristics such as self-magnification while fragility, mental preoccupation with success, feeling justified, expecting to be admired (Jafari \& Jajarmi, 2015). Imaginations are characterized by high power, beauty and success, high sensitivity to criticism, and a desire to exploit others in interpersonal relationships (Hill, 2013). Explaining this finding, we can say that narcissists are described as people who have dreams about their importance, infinite success, power, intelligence and beauty, and a sense of greatness. Characterized by this disorder are nagging self-loathing, constant narcissism, daydreaming about the unlimited success of power or beauty, and the need to show off to be admired. When criticized, the indifference of others and the threat to self-esteem are met with exaggerated responses to anger, shame, embarrassment, or futility. Those who score high on the narcissism test are relatively domineering, ostentatious, selfcentered, and extremist, and these traits are more likely to cause people with high levels of narcissism to engage in psychosocial mismatches and aggression, as a beneficial action (Haase \& Prapavessis, 2004).

For a person with narcissistic disorder or narcissism, others are the only means by which he or she can achieve his or her goals. Thus, the way narcissists think of others is how they can use them and use their support for a purpose. A person who does not comply with the wishes of such people, a person who does not agree with such people, or a person who does not consider them superior and special as they think they are, do not have an external existence in their eyes, and as the famous saying goes. This is why narcissists sometimes treat people rudely or inappropriately because they think others are the only tools they should use and if they no longer work or after they have achieved their goal, they treat them as if they were their own. Once upon a time, they were the companion of the cave and the companion of their caravan. Therefore, according to studies, if an athlete has a degree of narcissism, he cannot adapt to the situation and is low in terms of social and psychological adjustment. Accordingly, elite athletes are better able to adapt to the situation due to their low level of narcissism and perform successfully in their professional lives.

According to the results, it is concluded that the predictor variables of perfectionism and its components include (organization, personal criteria, skepticism about actions, excessive importance to error and perception of coach pressure) and narcissism has been able to predict psychosocial adjustment. In other words, the components of positive perfectionism include organizing and personal criteria positively, and the components of negative perfectionism include skepticism about actions, over-emphasis on error, and the perception of coach pressure and the narcissistic variable negatively have been able to predict psychosocial adjustment. Thus, the prediction of psychosocial adjustment is confirmed by combining perfectionism and narcissism in elite athletes. This finding is consistent with the findings of Arbab et al., (2015) (Arbab et al., 2016). The results of Arbab et al.'s (2015) study showed that sports perfectionism is negatively correlated with selfconfidence and positively correlated with trait anxiety (Arbab et al., 2016).

The results of stepwise regression showed that general perfectionism is the strongest predictor of trait anxiety and the pressure perceived by the instructor predicts cognitive anxiety and selfconfidence. Excessive worry about mistakes and personal standards also predicts physical anxiety. Accordingly, adjusting for perfectionism helps the athlete to be less affected by competitive anxiety and to increase self-confidence, thus increasing the likelihood of success and adaptation. Accordingly, perfectionism can predict the degree of adaptation in athletes. The results also indicate that narcissism can negatively predict psychological and social adjustment in national athletes (Arbab et al., 2016). Explaining these findings, it can be acknowledged that striving for perfection by enhancing a sense of self-worth, strengthening control, managing emotions in competition, and focusing and 
exercising on sports techniques increases mental performance, commitment, and social adjustment. It becomes. In contrast, a negative reaction to imperfection through psychological distress, impaired sense of self-worth, and impaired concentration and accuracy in the performance of sports techniques and skills reduces desirable performance and impairs athletic achievement and psychological social adjustment. Another explanation is that athletes, through extreme worries and doubts about their actions, are not able to experience the desired arousal and smooth execution, and they also suffer from inconsistencies and inconsistencies in timely identification and correction of their mistakes. Finally, despite his physical, technical, and tactical abilities, he may not be able to experience the peak of progress and adaptation due to the negative and extreme characteristics of perfectionism.

Also, based on the results, emphasizing the importance of positive perfectionism in the field of sports is valuable and should be encouraged and strengthened in athletes, and in contrast, the rate of negative perfectionism should be reduced. Striving to reach high standards for personal reasons and the ability to organize as positive dimensions of perfectionism can lead to higher levels of development and psychological social adjustment. On the other hand, narcissists usually feel superior and extraordinary, so if their value and credibility are compromised, they try to improve their affairs at the cost of destroying and even ruining the lives of others. They trample on others, degrade them, and humiliate them in order to make them feel superior. This is especially true in communications. Therefore, if athletes have a high degree of narcissism, their level of psychological and social adjustment in sports situations and competitions is reduced and as a result, they cannot perform successfully. Elite athletes are better able to adapt to the situation due to low narcissism and negative components of perfectionism and on the other hand are high in the dimensions of positive perfectionism and have good psychological and social adjustment. According to the results, it is concluded that there is a positive and significant correlation between perfectionism and psychological social adjustment in non-elite athletes. This means that with increasing perfectionism, psychological social adjustment increases and conversely, with decreasing perfectionism, the adjustment rate decreases. Among the components of positive perfectionism, only the organizational component has a negative correlation with psychological social adjustment, and the correlation of negative perfectionism components with positive psychological social adjustment is positive. This finding is consistent with the findings of Arbab et al. (2017) (Arbab et al., 2016). Explaining this finding, it can be said that non-elite athletes are at a lower level than elite athletes in terms of personality traits such as perfectionism and narcissism. In general, perfectionism creates problems in interpersonal relationships by shaping unrealistic expectations and criteria, and by critically evaluating and blaming oneself. This unfavorable situation causes the perfectionist to lose the opportunity and possibility of establishing a favorable relationship and, on the other hand, his main position with others. This vicious cycle causes the continuation and intensification of selfprocessing and psychological problems, a process that partly explains the correlation between perfectionism and psychological social adjustment. Also, in explaining this result, it can be said that the less psychological psychological adjustment of perfectionist non-elite athletes is due to the existence of characteristics such as intensification of inflexible ideal criteria, strengthening of unrealistic expectations, selective attention and extreme generalization of failures. Strict selfassessment is the tendency to think all or nothing and avoidance coping strategies. These characteristics are largely due to cognitive processes and ideal self-perception (Shaffer et al., 2015).

According to the results, it is concluded that there is a positive and significant relationship between narcissism and psychological and social adjustment of non-elite athletes. In other words, with the increase of narcissism, their adaptation increases and on the contrary, with the decrease of narcissism, their psychological and social adjustment decreases. This finding is consistent with the findings of Tazegul et al. (2017) in this field (Tazegül, 2017). Although no research has been done in this field so far, but the results of studies directly indicate that narcissism can negatively affect the success of athletes and thus their level of adaptation. In explaining this finding, we can say that narcissists think and feel like special and superior people, their desires must be met spontaneously and without any questions. They have a right to claim such a demanding behavior, so when this is not done, they get unreasonable anger or selfish rage.

Because they have a distorted perception of their importance and think that they are always right, if someone does not comply with their wishes, they will do their best to humiliate the person completely, without feeling any remorse. There are always people around them who reinforce their narcissism. There are always people who are attracted to these people and blow their narcissism with their behaviors. People are usually attracted to a narcissist who has low self-esteem, despises himself, and satisfies his self-injurious or masochistic tendencies in connection with a 
narcissist. On the other hand, narcissists, by constantly humiliating these people, both maintain their superiority and inadvertently make them obedient by doing so. According to these explanations, non-elite athletes, due to having such attitudes and views towards others and looking up and down, are less able to adapt to the situation and their psychological and social adaptation is low. From an interpersonal perspective, narcissists are notable for their sense of legitimacy and consequent lack of empathy for others. Cognitively, narcissists have replaced fantasy and imagination with reality. In terms of evolutionary approach, the narcissist has a passive orientation towards himself (Arbab et al., 2016).

From a social learning perspective, on the other hand, narcissism is likely to occur if the parents of people constantly devalue them and create a selfimage for them that they cannot maintain themselves in the real world. Narcissism is a pervasive disorder characterized by selfcenteredness, a lack of empathy for others, and an exaggerated sense of self-concept. Like other personality disorders, this disorder creates a stable pattern of behavior, which negatively affects many different aspects of life such as social, family and work relationships. Researchers think that childhood experiences, such as parental overfacilitation, child-rearing, growing admiration, insecure upbringing, and lack of realistic reaction, all contribute to narcissism (Arbab et al., 2016). Therefore, non-elite athletes seem to be more narcissistic due to different living conditions and family environment, and as a result, they are low in psychological and social adjustment.

According to the results, it can be concluded that the predictor variables of perfectionism and its components including (excessive importance by mistake, perception of parental pressure and perception of coach pressure) and narcissism have been able to improve psychosocial adjustment. In other words, among the components of perfectionism, only the negative components, including over-emphasis on error, perception of parental pressure and perception of coach pressure, as well as the narcissistic variable, have been able to positively improve psychosocial adjustment in non-elite athletes. This finding is consistent with previous findings in this field (Jafari \& Jajarmi, 2015). Jafari et al. (2012) showed that there is a significant relationship between perfectionism and coping strategies with burnout in football athletes (Jafari \& Jajarmi, 2015). Perfectionism, through effective cognitive-behavioral mechanisms, modulates the relationship between coping strategies and burnout in footballers and affects the adjustment of individuals.

Explaining this finding, we can say that positive or adaptive perfectionism, with high but achievable personal standards, tendency to order and organize in affairs, feeling satisfied with one's performance, seeking excellence in affairs and motivation to achieve it is characterized by positive rewards. Negative or maladaptive perfectionism with high and unrealistic standards, excessive worry about errors and cognitive defects, perceived high pressure from the environment for perfection, perceived long distance between personal performance and standards, forced skepticism And avoid the consequences of personal actions. Therefore, one of the characteristics of perfectionists is the tendency to perform perfect activities. These people, even when they do something satisfactorily, still have doubts about their performance, and this factor causes them to have low psychological and social adjustment. Therefore, non-elite athletes suffer from low psychological and social adjustment due to their perfectionist characteristics. On the other hand, narcissism can lead to personality disorders, and like other personality disorders, this disorder can lead to a stable pattern of behavior, which has a negative impact on many different aspects of life, such as social, family and work relationships. It has undesirable consequences and consequences, including social and social incompatibility. According to theoretical principles, because narcissistic athletes have a sense of self-worth and the most important thing for a narcissistic athlete is victory, and also because they engage in immoral behaviors in order to achieve their goals, this However, these athletes may also have narcissistic personality disorder and may not be in a good position in terms of personality and psychological characteristics and may have irrational and incorrect behaviors.

Therefore, in order to prevent the occurrence of narcissistic personality disorder behaviors, officials and stakeholders with the help of psychologists can provide appropriate educational and therapeutic programs to reduce the negative dimensions of perfectionism and maladaptive narcissistic behaviors and moral and behavioral problems. Take action on these athletes to prevent future problems in the sports community. The knowledge gained from this research can provide valuable information for coaches and sports officials. Therefore, coaches should be aware of athletes who have negative perfectionism and, with the help of a sports psychologist, try to moderate this personality trait to prevent the athlete from becoming aggressive in order to increase his or her psychological and social adjustment in competitions and sporting events.

\section{Conclusions}

Therefore, in general, based on the research results, it can be said that psychological and social adjustment in athletes is one of the key variables in 
the professional and personal life of athletes, which is influenced by characteristics such as perfectionism and narcissism. According to the results, in elite athletes positive perfectionism has a positive relationship with psychological social adjustment and negative perfectionism and narcissism as negative characteristics have a negative correlation with psychological social adjustment and in non-elite athletes positive perfectionism with Negative adaptation and negative characteristics such as negative perfectionism and narcissism are negatively associated with psychological social adjustment.

Author Contributions: "Conceptualization, M.HN. And M.HS; methodology, M.HN. And M.HS; software, M.HN. And M.HS; validation, M.HN. And M.HS; formal analysis, M.HN. And M.HS; investigation, M.HN. And M.HS; resources, X.X.; data curation, X.X.; writingoriginal draft preparation, X.X.; writing-review and editing, X.X.; visualization, M.HN. And M.HS; supervision, M.HN. And M.HS; project administration, M.HN. And M.HS; funding acquisition, M.HN. And M.HS. All authors have read and agreed to the published version of the manuscript

Funding: This research received no external funding

Data Availability Statement: Not applicable

Acknowledgments: The authors of this article would like to thank all the participants in this study

Conflicts of Interest: The authors declare no conflict of interest

\section{References}

Arbab, B., Vaez Moosavi, M. K., \& Badami, R. (2016). The relation between sports perfectionism and competitive anxiety in women's national karate team. Research in Sport Management and Motor Behavior, 5(10), 27-35. [Google Scholar]

Baddeley, A. (1992). Working memory. Science, 255(5044), 556-559. [Google Scholar]

Besharat, M. A., Agham Mohammadian, M. R., \& Heidari, F. (2021). Perfectionism and selfesteem in physical education students. Behavioral Sciences Research, 2, 25-50. [Google Scholar]

Cai, H., \& Luo, Y. L. L. (2018). Distinguishing between adaptive and maladaptive narcissism. In Handbook of trait narcissism (pp. 97-104). Springer. [Google Scholar]

Cox, R. H., \& Yoo, H. S. (1995). Playing position and psychological skill in American football. Journal of Sport Behavior, 18(3), 183. [Google Scholar]
Czarna, A. Z., Zajenkowski, M., Maciantowicz, O., \& Szymaniak, K. (2019). The relationship of narcissism with tendency to react with anger and hostility: The roles of neuroticism and emotion regulation ability. Current Psychology, 1-16. [Google Scholar]

Enns, M. W., Cox, B. J., \& Clara, I. (2002). Adaptive and maladaptive perfectionism: Developmental origins and association with depression proneness. Personality and Individual Differences, 33(6), 921-935. [Google Scholar]

Foster, J. D., Shenesey, J. W., \& Goff, J. S. (2009). Why do narcissists take more risks? Testing the roles of perceived risks and benefits of risky behaviors. Personality and Individual Differences, 47(8), 885-889. [Google Scholar]

Grijalva, E., \& Newman, D. A. (2015). Narcissism and counterproductive work behavior (CWB): Meta- analysis and consideration of collectivist culture, Big Five personality, and narcissism's facet structure. Applied Psychology, 64(1), 93126. [Google Scholar]

Haase, A. M., \& Prapavessis, H. (2004). Assessing the factor structure and composition of the Positive and Negative Perfectionism Scale in sport. Personality and Individual Differences 36(7), 1725-1740. [Google Scholar]

Hamachek, D. E. (1978). Psychodynamics of normal and neurotic perfectionism. Psychology: A Journal of Human Behavior. [Google Scholar]

Hill, A. P. (2013). Perfectionism and burnout in junior soccer players: A test of the $2 \times 2$ model of dispositional perfectionism. Journal of Sport and Exercise Psychology, 35(1), 18-29. [Google Scholar]

Houlcroft, L., Bore, M., \& Munro, D. (2012). Three faces of narcissism. Personality and Individual Differences, 53(3), 274-278. [Google Scholar]

Jafari, S., \& Jajarmi, M. (2015). The relationship between self-efficacy and perfectionism with social adjustment in high school female students in Bojnourd. The first scientific conference on psychology, educational sciences and community pathology, Kerman. [Google Scholar]

Kaplan, H. I., \& Sadock, B. J. (1988). Synopsis of psychiatry: Behavioral sciences clinical psychiatry. Williams \& Wilkins Co. [Google Scholar]

Nascimento Junior, J. R. A. d., Batista, R. P. R., Silva, A. A. d., Granja, C. T. L., Fiorese, L., \& Fortes, L. d. S. (2020). Is an athlete's perfectionism associated with the performance of indoor football teams? Psicologia: teoria $e$ prática, 22(2), 317-337. [Google Scholar]

Nasiri, A. H. (2019). Investigating the relationship between the dimensions of parental perfectionism and mental health and social adjustment of high school students in Bayram. 
The second national conference on curriculum change, Lamerd. [Google Scholar]

Öngen, D. E. (2009). The relationships between perfectionism and aggression among adolescents. Procedia-Social and Behavioral Sciences, 1(1), 1073-1077. [Google Scholar]

Park, H.-j., \& Jeong, D. Y. (2015). Psychological well-being, life satisfaction, and self-esteem among adaptive perfectionists, maladaptive perfectionists, and nonperfectionists. Personality and Individual Differences, 72, 165170. [Google Scholar]

Pourramzani, A., \& Monajemi, E. (2021). Prevalence of Adaptive Narcissism and Its Demographic Correlations Among the Interns of Guilan University of Medical Sciences, Medical Faculty: A Cross-sectional Study. Iranian Journal of Psychiatry and Behavioral Sciences, 15(1). [Google Scholar]

Pulakos, E. D., Schmitt, N., Dorsey, D. W., Arad, S., Borman, W. C., \& Hedge, J. W. (2002). Predicting adaptive performance: Further tests of a model of adaptability. Human performance, 15(4), 299-323. [Google Scholar]

Razmara, M. (2017). A study of cognitivebehavioral stress management training on psychological well-being, psychosocial adjustment and quality of life in patients with epilepsy University of Kerman]. [Google Scholar]

Rice, K. G., \& Dellwo, J. P. (2002). Perfectionism and self- development: Implications for college adjustment. Journal of counseling \& development, 80(2), 188-196. [Google Scholar]

Sedikides, C., Rudich, E. A., Gregg, A. P., Kumashiro, M., \& Rusbult, C. (2004). Are normal narcissists psychologically healthy?: Self-esteem matters. Journal of personality and social psychology, 87(3), 400. [Google Scholar]

Shaffer, C. T., Tenenbaum, G., \& Eklund, R. C. (2015). Implicit theories of mental skills abilities in collegiate athletes. Journal of Applied Sport Psychology, 27(4), 464-476. [Google Scholar]

Smith, M. B., \& Webster, B. D. (2018). Narcissus the innovator? The relationship between grandiose narcissism, innovation, and adaptability. Personality and Individual Differences, 121, 67-73. [Google Scholar]

Stoeber, J. (2018). The psychology of perfectionism: Critical issues, open questions, and future directions. [Google Scholar]

Stoeber, J., \& Otto, K. (2006). Positive conceptions of perfectionism: Approaches, evidence, challenges. Personality and social psychology review, 10(4), 295-319. [Google Scholar]

Sukhov, A. N., \& Derkach, A. A. (1998). Prikladnaya sotsial'naya psikhologiya [Applied social psychology]. Moscow: Modek. [Google Scholar]

Tazegül, Ü. (2017). The Determination Of The Relationship Between Narcissism And Positive Thinking Levels Of Physical Disabled Athletes. European Journal of Social Sciences Studies. [Google Scholar]

Vatankhah, M., \& Samani, S. (2016). Mediating Role of Achievement Motivation for Perfectionism and Achievement Goal in Professional Athletics. [Google Scholar]

Vink, K., \& Raudsepp, L. (2018). Perfectionistic strivings, motivation and engagement in sportspecific activities among adolescent team athletes. Perceptual and motor skills, 125(3), 596-611. [Google Scholar]

Waleriańczyk, W., \& Stolarski, M. (2021). Personality and sport performance: The role of perfectionism, Big Five traits, and anticipated performance in predicting the results of distance running competitions. Personality and Individual Differences, 169, 109993. [Google Scholar]

Watson, P. J., \& Biderman, M. D. (1993). Narcissistic Personality Inventory factors, splitting, and self-consciousness. Journal of personality assessment, 61(1), 41-57. [Google Scholar]

Zarei Mousavieh, M. (2016). Predicting student adjustment based on perfectionism and social support Tarbiat Dabir Shahid Rajaei University]. [Google Scholar] 


\title{
فصلنامه رويكرد انسانى در مطالعات ورزشى
}

$\underline{\mathrm{HA}}>\mathrm{E} \mathrm{S}$

http://hasesjournal.com/

\section{رابطه كمال كر ايعى و خودشيفتَى با ساز كارى اجتماعى روانى در ورزشكاران نخبه و غير نخبه}

\section{محمد حسين نامور (1)}

\author{
كروه تربيت بدنى، واحد تبريز، دانشخاه آزاد اسلامى، تبريز، ايران
}

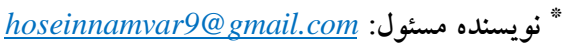

جُهيده: يُزوهش حاضر با هدف بررسى رابطه كمالگرايى و خودشيفتكى با ساز گارى

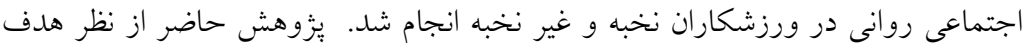

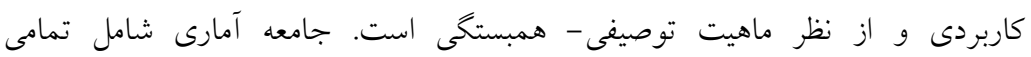
ورزشكاران (نخبه و غيرنخبه) شهر تبريز با دامنه سنى •r-19 سال بود كه در سال 94ها

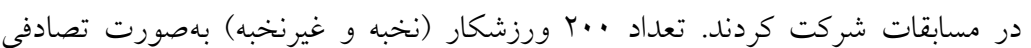

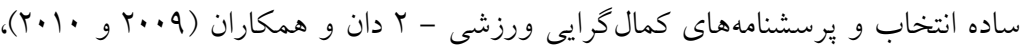
يرسشنامه خوشيفتكى راسكين و ترى و يرسشنامه ساز گارى اجتماعى بل را را تكميل

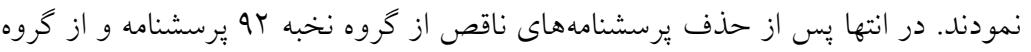

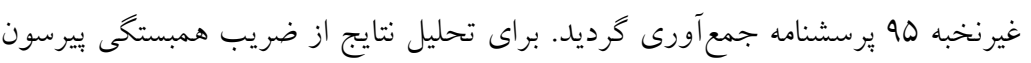

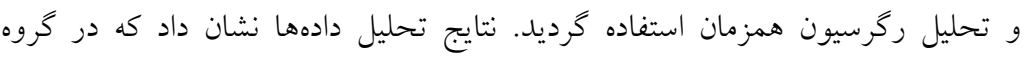
ورزشكاران نخبه بين كمال گرايى مثبت (سازماندهى و معيارهاى شخصى) با سازگارى رتي اجتماعى روانى همبستكى مثبت و بين كمال كرايى منفى (شك و ترديد نسبت به اعمال، ادراى فشار والدين و ادراك فشار مربى) و خودشيفتكى با سازكارى اجتماعى روانى

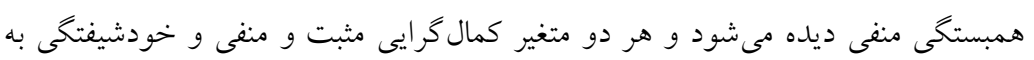

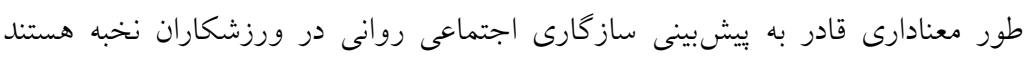

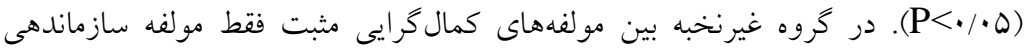
داراى همبستگى منفى با سازكارى اجتماعى روانى است و همبستكى مولفههاى كمال كرايى منفى و خودشيفتكى با ساز گارى اجتماعى روانى مثبت است. همجنين نتايج تحليل رگرسيون در گروه غيرنخبه نشان داد كه از بين مولفههاى كمال گرايى تنها مولفه هاى منفى (اهميت بيش از اندازه به اشتباه، ادراى فشار والدين و ادراى فشار مربى) و و و متغير خودشيفتكى توانستهاند به طور مثبى سازگارى اجتماعى روانى را بيشبينى نمايند

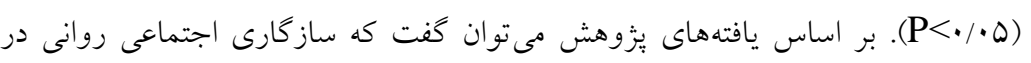

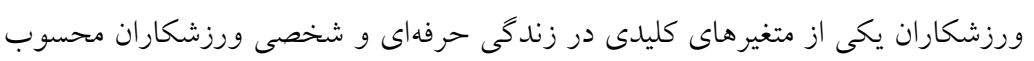

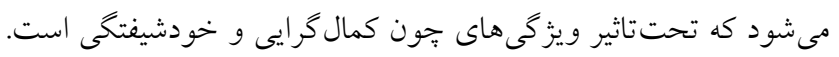
وازههاى كليدى: كمال كرايى، خودشيفتكى، ساز كارى اجتماعى روانى، ورزشكار، نخبه، غير نخبه؛
ارجاع: نامور ، م. (F) (IF). رابطه كمال

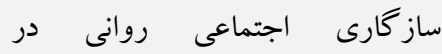
ورزشكاران نخبه و غير نخبه. فصلنامه رويكرد انسانى در مطالعات ورزشى. $.9 Y-\Delta \cdot: !(1)$

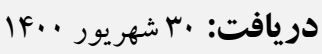

$$
\begin{aligned}
& \text { يذيرش: اب مهر . . } \\
& \text { انتشار: 1 | آبان . If }
\end{aligned}
$$

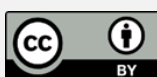

اين نماد به معناى مجوز استفاده از اثر با دو شرط است يكى استناد به نو يسنده و ديخرى استفاده براى مقاصد غير تجارى. 